\title{
The Density of Coliform Bacteria Indicators of Pollution in the River Right Labuhanbatu Selatan
}

\author{
Yatini $^{1}$, Arman Harahap ${ }^{2}$ \\ ${ }_{1,2}$ Faculty of Teacher Training and Education, Universitas Labuhanbatu, Indonesia \\ armanhrp82@yahoo.cco.id
}

\begin{abstract}
Coliform bacteria is a one of a kind negative bacteria that is commonly found marine waters, the presence of coliform bacteria can be an indicator of biology that is important to know the environmental conditions. This study aims to determine the environmental conditions based on biological indicators in the form of an abundance of coliform bacteria in the waters of the River right District Labuhanbatu Selatan. The main ingredient in this study is the River right and sediment. The results of the analysis showed the density of coliform bacteria in the study site ranged from 500-700 colonies $/ \mathrm{ml}$ for the sample waters and $27-$ $120 \mathrm{MPN} / \mathrm{g}$ for sediment samples. The results obtained are still below the quality standard so that the river right in good condition biologically. The presence of coliform bacteria in the river can affect human and biota. So it needs to be considered in the efforts of the management of the coastal environment, particularly in efforts to maintain the sustainability of fisheries resources
\end{abstract}

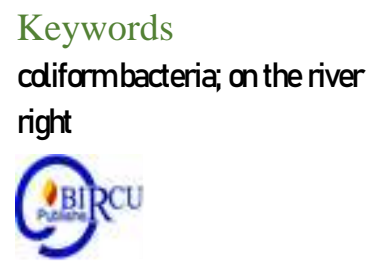

\section{Introduction}

River region Right have problems, among other natural factors, in terms of society and the problems caused by anthropogenic factors. Anthropogenic factors are the factors that could potentially result in a conflict that such a large, weighing pressure exploitation of coastal resources as well as the rapid rate of pollution gradually. Pollution is influenced by the influx of waste, both domestic, and industry that result in a decline in water quality and productivity of the ecosystem (Shah 2010). According to Hamuna (2018) in the waters of the sea will be found in various types of garbage and pollutants, it certainly can lead to environmental degradation in the region of the river and surrounding ecosystem.

Excessive have a devastating impact on the waters of the sea and cause a decrease in sea water quality: physical, chemical, and biological. According to Girard (2003) Contamination of biological can be known with the exploration of microbial as the microorganisms in the river, which can be carried and used as information environmental conditions. Some microbes can be used as the parameters of the indicators of environmental pollution is one of coliform bacteria that grow and thrive in the waters. Parameters of microbiology is used as bio-indicators of the beginning of the pollutant waters derived from the waste of domestic, industrial waste, garbage and sewage farm the River District Right-have a condition that is interesting to do research due to the activity of people who have good physical conditions is not necessarily the condition of its biological shows a state of good condition. For that the need for this experiment is to determine the biological condition of using the indicator of the presence of the bacteria colifom as an early indicator of the condition of the aquatic environment of the River Right District Labuhanbatu Selatan. The definition of pollution in the Regulations of the Republic of Indonesia Number 82 Year 2001 on Water Quality Management and Water Pollution 
Control states, water pollution is indicated by the decline in the quality of water up to a certain level which causes the water to not function as intended. Certain level such is the quality of the raw water is set and serves as a benchmark to determine the rate of occurrence of pollution of waters. Assessment of quality of the raw waters in addition to are based on the designation, also based on the real conditions of water quality which may vary from one region to the other.

Coliform bacteria is a group of intestinal bacteria that live in the human digestive tract. Coliform bacteria itself is a bacterial indicator of the presence of pathogenic bacteria to another. More precisely coliform bacteria fecal bacteria indicators of the presence of bacterial contamination of pathogens. Determination of coliform faecal be indicators of pollution due to the number of colonies that certainly positively correlated with the presence of pathogenic bacteria.

Coliform bacteria itself arises because of the waste of human feces as well as laundry wastewater from households that oozes from the river-the river and caused also by pollution eyes water or raw water, the weakness of the filtration system.

Coliform is a group of bacteria used as indicators of the presence of pollution dirt and sanitary conditions are not good against water, food, milk, and milk products. The presence of coliform bacteria in the food and beverage showed the possibility of the presence of microorganisms that are enteropatogenikdan/toxigenic that are harmful to health. Coliform bacteria can be divided into two groups, namely : (1) coliform faecal, for example Escherichia coli, and (2) coliform non-faecal, for example Enterobacter aerogenes. Escherichia coli is a bacteria that comes from the feces of animals and humans, while Enterobacter aerogenes is usually found in animals or plants that have died (Irianto, 2013). Bacteria of group of coliform expressed as a bacterial indicator of water pollution. Its presence especially water sources bathing, washing, and toilet very not expected. Examination of the bacteria of group of coliforms carried out against the presence of bacteria of group of coliform non;fecal and coliform bacteria fecal. To know the number of coliforms in a sample can be used the method of the figures most probably (MPN) of coliform bacteria. The principle of this method is the fermentation of lactose for 24 hours by the coliform bacteria that will produce acid and gas which is caught by the tube Durham in test tubes (Husna, 2014). Normally, Coliform bacteria also contained in the waters of a certain amount. However, when the contamination of water then the number of Coliform will be a lot more above the threshold and may exceed the amount of pathogenic bacteria to another. Therefore, if Coliform bacteria is contained in large quantities above the threshold, it is necessary to check for the presence of pathogenic bacteria other (Inggrid S Surono et al., 2012). Coliform bacteria have the ability to decipher lactose as a carbon source, whereas the group of intestinal microorganisms that others can not do. As an indicator of the process of decomposition of lactose to acid, into the medium added indicators Bromcressol purple (Bcp) purple and yellow in an acid.

Coliform is a group of bacteria that can be used as an indicator of pollution dirt and salinity are not good against the waters. The presence of coliform bacteria in the waters of the sea suggests the possibility of the presence of microorganisms that are eterpatogenetik and taksigenetik that is able to affect the health of the biota and humans (Wanda 2012). Coliform bacteria include all bacteria are rod-shaped, gram-negative, do not form spores and at a temperature of $37^{\circ} \mathrm{c}$ in less than 48 hours can ferment lactose to produce gas and acid (Suharyono 2008). 


\section{Research Methods}

The waters of the River Right Kabupaten Labuhanbatu Selatan, samples were taken of water and sediment, in which there are 3 stations and each station has 3 point research.Station I-Latitudes ( 1050'46.54"n ) and Longitude ( 10004'31.33'T ), Station II Lines of Latitude ( 1051'24.89"n ) and Longitude ( 10006'6.65"T ), Station III Latitudes ( $10522^{\prime} 38.76$ 'N) and Longitude (10006'50.24'T ). Research station for sampling distinguished based on the consideration of the environmental conditions in the water area.

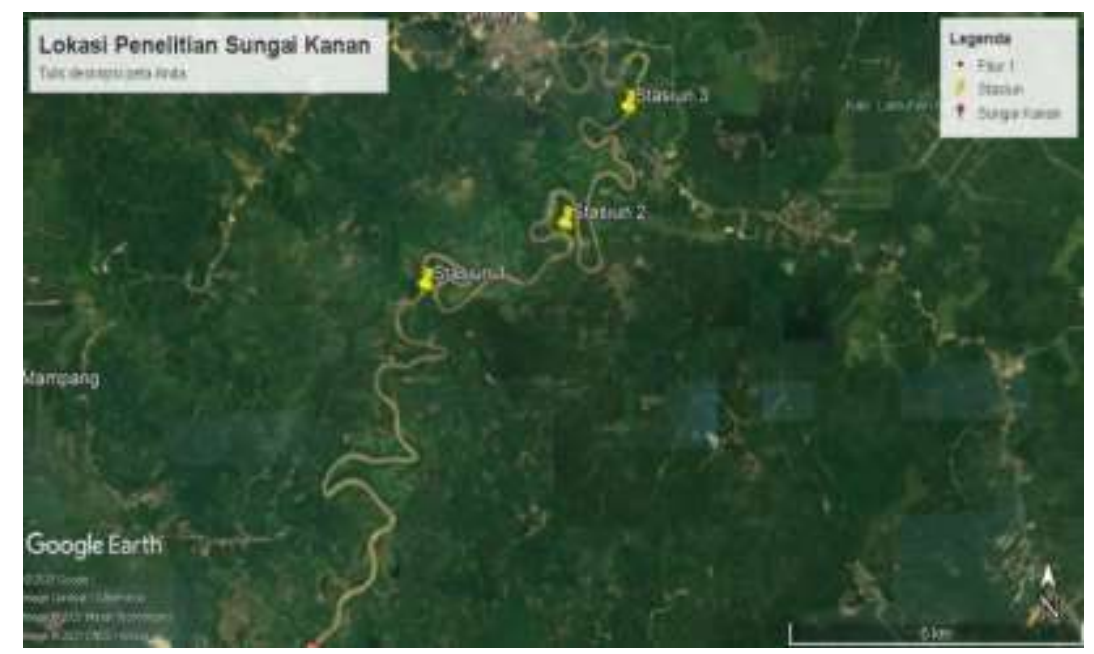

Figure 1. Location Research

Sampling of research is taken directly in the waters of Kabupaten Labuhanbatu Selatan done based on purposive sampling technique, where the waters of the River Right much in use as a farm, transportation, irrigation and other. Sampling of water and sediment carried in 3 research station.

\subsection{Sample Waters}

Analysis of coliform bacteria water samples in this study using the method of membrane filters. The first filter samples of sea water $100 \mathrm{ml}$ using the membrane filter with the tool manifolt membrane filter, next menjapit membrane filter and move it to the media TTC (in laying the membrane filter into the media TTC no trapped air underneath), incubation of media at a temperature of $360 \mathrm{C}$ for $2 \times 24$ hours. Do the observations of the growth and changes in the bacteria that filtered in membrane filter, if the results of the positive coliform bacteria will form colonies that are yellow to orange. Test booster with transfer of bacteria that grow on TSA media $0 \%$ and TB, incubation TSA $0 \%$ in the temperature of $45 \mathrm{oC}$ for TB incubation in the temperature of $36 \mathrm{oC}$. The last count the amount indicated coliform bacteria. The use of the method of membrane filters produce bacteria in the form of colonies. The technique of membrane filter in a statistical result can be calculated directly and precisely. The density of bacteria colony can be calculated with the density per $100 \mathrm{ml}$, the formula calculation according to APHA (1979) and the WHO (1977) as follows: Total bacteria $/ 100 \mathrm{ml}=$ Total bacterial colonies $\mathrm{x} 100$ (the volume of water filtered). The ministry of Environment 2006, stating that the quality standard for coliform bacteria 1000 colonies/100ml. 


\subsection{Sediment Samples}

Analysis of coliform bacteria to sediment samples in this study refers to the research Pelczar (1988), namely the method of multiple test tube. The first sediment samples of 250 $\mathrm{g}$ was dissolved in a solution of BFP $250 \mathrm{ml}$ and stacometer so homogeneous. Keduamenyiapkan 9 test tubes containing media LB $9 \mathrm{ml}$ inside there is durham, move $1 \mathrm{ml}$ sample into the medium LB rank three (10-1, 10-2, and 10-3) and dilution, inklubasi for $2 \times 24$ hours (observe if there are bubbles on the tube durham and the color of the solution turbid identified bacteria contained coliform bacteria). The third test booster, samples bubbly transferred to a solution of BGLB, inklubasi for $2 \times 24$ hours. If there is a bubble in the tube durham and the colors look murky means identified coliform bacteria. The use of the method of multiple test tube compare the results only based on the number of bacteria approximate nearest is expressed in MPN (Most Probable Number). Then the results compared with the quality standards Kep-51/MENKLH/2004, stating that the quality standard for coliform bacteria in the sea is a $1000 \mathrm{MPN} / \mathrm{g}$.

\section{Results and Discussion}

The results of the test coliform bacteria waters (Table 1.) using the methods of sieve membrane (membrane filter). The technique of membrane filters is a good technique for the examination of waste water for bacteriological ( american public health sociation 1976). Principle. the working technique of the membrane filter is based on the overhang of the particles of the sample, which passes through the top surface of the membrane filter (Cotton 1974).

Table 1.The Results Of The Test Waters

\begin{tabular}{|l|c|}
\hline Location & $\begin{array}{c}\text { Number of Coliform Bacteria } \\
\text { (colony / 100ml) }\end{array}$ \\
\hline Station I & 500 \\
\hline & 600 \\
\hline & 500 \\
\hline Station I & 500 \\
\hline & 500 \\
\hline & 600 \\
\hline Station I & 500 \\
\hline & 800 \\
\hline & 700 \\
\hline
\end{tabular}

\section{The Analysis of the Contamination of Coliform Waters of the River Right}

The river Right Kabupaten Labuhanbatu Selatan in this study has three stations, from the results of the research environment parameters stasiunI, II, and III $\mathrm{pH}$ value in accordance with the quality standards, while for temperature, DO, and salinity is not in accordance with the quality standard of the waters (Table 2). The third research station has the potential for the growth of coliform bacteria (Table 3 ). 
Table 2.The Parameters Of The Growth Of Coliform Bacteria

\begin{tabular}{|c|c|c|c|c|c|c|c|}
\hline \multirow[b]{2}{*}{ Parameters } & \multicolumn{4}{|c|}{$\underline{\text { Location Research }}$} & \multirow[b]{2}{*}{ Bacteria } & \multirow[b]{2}{*}{ Source } & \multirow[b]{2}{*}{ Conditions } \\
\hline & Station I & Station & II & Station III & & & \\
\hline Suhu $\left({ }^{0} \mathrm{C}\right)$ & 20,9 & 33,7 & & 33,1 & 1242 & Herd (2001) & Tools \\
\hline $\mathrm{DO}(\mathrm{mg} / \mathrm{L})$ & 4,56 & 3,51 & & 4,36 & $>6$ & $\begin{array}{l}\text { Adrianto } \\
\text { (2018) }\end{array}$ & No Tools \\
\hline $\begin{array}{l}\text { Salinitas } \\
\text { (ppt) }\end{array}$ & 22 & 25 & & 24 & $<75$ & Herd (2001) & Tools \\
\hline $\mathrm{Ph}$ & 6,5 & 8,7 & & 7,7 & $7,3-6,5$ & Salle (2000) & Tools \\
\hline
\end{tabular}

According to Tururaje (2010), coliform bacteria is an indicator of environmental contamination or poor sanitation as well as indicators of fecal contamination from humans and warm-blooded animals. Coliform bacteria have a higher durability of the pathogenic bacteria, as well as other more easily isolated and grown (Sutiknowati 2018). Increase of temperature, moisture and $\mathrm{pH}$ in an environment cause the occurrence of the proliferation of pathogenic bacteria (Salvation 1997). Temperature conditions that support the growth of coliform bacteria is $12-440 \mathrm{C}$, while the salinity range for growth of coliform bacteria that is not greater than 85 ppt (Herd 2001). Salle (2000) states marine bacteria able to grow at $\mathrm{pH} 6,5-8,7$ but the growth optimum of 7.3 to 6.5 .

According to Andrianto (2018), the levels of dissolved oxygen in the water is a good $>6 \mathrm{mg} / \mathrm{L}$. The results of the study parameters DO less optimum for the growth of coliform bacteria, this shows that the absence of activity of the agricultural-intensive as well as there are types of bacteria that require oxygen in his life. Pasco et. al (2003), the value of the DO low indicates that the absence of activity of agriculture is intensive in the area considering the rest of the fertilizer is one of the sources of pollutants coliform bacteria. Ali (2013), aerobic bacteria are bacteria that life requires free oxygen for example Nitrosomonas and Acetobacter, while anaerobic bacteria is a type of bacteria that can live without free oxygen for example Escherichia coli and Aerobacter.

According to Andrianto (2018), the levels of dissolved oxygen in the water is a good $>6 \mathrm{mg} / \mathrm{L}$. The results of the study parameters DO less optimum for the growth of coliform bacteria, this shows that the absence of activity of the agricultural-intensive as well as there are types of bacteria that require oxygen in his life. Pasco et. al (2003), the value of the DO low indicates that the absence of activity of agriculture is intensive in the area considering the rest of the fertilizer is one of the sources of pollutants coliform bacteria. Ali (2013), aerobic bacteria are bacteria that life requires free oxygen for example Nitrosomonas and Acetobacter, while anaerobic bacteria is a type of bacteria that can live without free oxygen for example Escherichia coli and Aerobacter. The noise density of coliform bacteria become one indication of the quality of the environment, there is still the need for further research to determine the indicator-other indicators to be important factors to determine the conditions and the quality of the environment. It is very important in the efforts of the management of the environment, particularly in efforts to use natural resources in coastal and marine areas. According to Wahyuni (2016), stated that the condition of the physics of the waters of the well is not necessarily the conditions of the biology of the waters are also better on the same waters. 


\section{Conclusion}

Based on the research and analysis that has been done can be concluded that There are coliform bacteria in the waters of the average 500-700 colonies $/ \mathrm{ml}$, whereas the sediment average 27-120 MPN/g. As for the status of pollution in biology in the waters of the River Right is still below the quality standard.

\section{References}

American Public Health Association. (1976). Standart Method For The Examination Of Water And Wastewater APHA- AWWA-WPCF. Washington: 1193 pp.

Girard, F., Batisson, I., Harel J., Fairbrother,J. M. (2003). Use Of Egg Yolk-Derived Immunoglobulins as an Alternative to Antibiotic Treatment for Control of Attaching and Effacing Esherichiacoli

Hamuna, B., Tanjung, R.H.R., Suwito., Maury, H.K., Alianto. (2018). Kajian Kualitas Air Laut dan Indikasi Pencemaran Berdasarkan Parameter Fisika-Kimia Di Perairan Distrik Depapre, Jayapura. Jurnal Ilmu Lingkungan, 16(1),35-43.

Herd, T., Crowlker J.S. (2001). Food security for nutritionists. I CD-SEAMEO-GT2WHO.

Husna, R. 2014. Mini Riset Mikrobiologi Terapan. Yogyakarta.

IInfection. General Meeting of American Society for Microbiology. Washington D. C. Virginie, USA.

Irianto, K. 2013. Mikrobiologi Medis. Bandung.

Iggrid S Surona dkk. 2012. Pengantar Keamanaan Pangan. Yogyakarta.

Kristanto, P. (2002). EkologiIndustri.

Yogyakarta: Penerbit Andi.

Lisdayanti, E. (2013). Potensi Antibakteri Dari Bakteri Asosiasi lamun (Seagrass) Dari Pulau Bonebatang Perairan Kota Makassar. Skripsi. Universitas HasanuddinMakassar.

Pratiwi, R. (2013). Distribusi Bakteri Coliform di SITU Ciledong Depok Jawa Barat. Skripsi. Universitas IndrapuraPGRI.

Priyanto, A. (2009). Uji Bakteriologi Air Baku Dan Siap Konsumsi Dari PDAM Surakarta Ditinjau Dari Jumlah Bakteri Coliform. Skripsi. Fakultas Keguruan Dan Ilmu Pendidikan Universitas Muhammadiyah Surakarta

Salle, A.J. (2000). Fundamental Principles Of Bacteriology. 8. Harper \& Brothers.

Sutiknowati, L.I. (2018). Keragaman Bakteri Pada Perairan Sabang, Provinsi Aceh. Majalah Ilmiah Biologis Biosfera: A. Scientific Journal, 35(2), 54-62.

Suharyono. (2008). Diare Akut Klinik dan Labooratorik. Jakarta Cipta: Jakarta.

Syah, A. F. (2010). Indikasi Kenaikan Muka Air Laut di Pesisir Kabupaten Bangkalan Madura (Doctoral dissertation, Tesis Fakultas Teknik Jurusan Teknik Kelautan Universitas Trunojoyo. Madura).

Wanda, S. M. (2012). Analisa Bakteri Coliform (Fekel dan Non Fekel) Pada Air Sumur Di Komplek Roudi Manokwari. Skripsi. Program Studi Biologi Universitas Negeri Papua.Manokwari 